Article

\title{
Gob-Side Entry Retaining Involving Bag Filling Material for Support Wall Construction
}

\author{
Zhaowen Du ${ }^{1,2}$, Shaojie Chen ${ }^{1,2, *}$, Junbiao $\mathrm{Ma}^{2}$, Zhongping Guo ${ }^{2}$ and Dawei Yin ${ }^{1,2, *}$ \\ 1 State Key Laboratory Breeding Base for Mining Disaster Prevention and Control, Shandong University of \\ Science and Technology, Qingdao 266590, China; qddzw3215@sdust.edu.cn \\ 2 College of Energy and Mining Engineering, Shandong University of Science and Technology, \\ Qingdao 266590, China; 18135836658@163.com (J.M.); gzp57046@126.com (Z.G.) \\ * Correspondence: chensj@sdust.edu.cn (S.C.); yindawei@sdust.edu.cn (D.Y.)
}

Received: 25 June 2020; Accepted: 5 August 2020; Published: 7 August 2020

\begin{abstract}
Gob-side entry retaining, also termed as non-pillar mining, plays an important role in saving coal resources, high production and efficiency, extending the service life of mine and improving the investment benefit. Herein, a gob-side entry retaining method involving the use of bag filling material for wall construction is proposed based on the thin seam mining characteristics. First, a gob-side entry retaining mechanical model is established, and the side support resistance of the 8101 working face is calculated. The mechanical properties of the bag material are investigated through experiments, and the construction technology of the gob-side entry retaining approach involving the use of bag filling material for wall construction is introduced. The deformation on the two sides, the roof and floor of the roadway, are simulated via numerical methods and monitored during field tests. The results show a small control range for the deformations and a good roadway retention effect, thereby proving the feasibility of the bag filling material for wall construction. This study provides a reference for the development of gob-side entry retaining mining for thin coal seams.
\end{abstract}

Keywords: gob-side entry retaining; bag filling material; support body; construction technology; field monitoring

\section{Introduction}

Gob-side entry retaining involves the preservation of the entire tailgate of the previous working face for use in the next one [1-3]. This allows for the utilization of a single roadway for two working faces. The key feature of this technology is the construction of a wall (also termed roadway side) to replace the traditional method of retaining coal pillars at the end support and along the working face [4-6]. The constructed wall that replaces the traditional coal pillar is employed for supporting the roof and isolating the goaf. This prevents air leakage from the goaf and provides the required support capacity. Accordingly, the side support of the roadway is preserved for the next working face. Consequently, the constructed roadway wall can form a transport roadway satisfying Y-type ventilation safety and production requirements. Concurrently, the wall's structure must withstand the impact of the second overburden movement [7-10]. The gob-side entry retaining technology is characterized by direct significant effects including coal resources saving, investment benefit improvement, and mining life prolongation. In particular, its impacts on high-quality and rare resources are remarkable [11-16].

At present, gangue backfilling, concrete pier, paste backfilling, and roof cutting with a single hydraulic density support are the mostly used roadway side support systems. For example, Zhang et al. [17] analyzed the deformation and failure of the gob-side entry retaining roof for a thin seam with a high dip angle. Additionally, Zhou et al. [18] exploited the natural phenomenon of a falling gangue and self-sliding in the goaf of an inclined coal seam to advance the filling method 
combining flexible and rigid supports in roadway support construction and goaf filling. Furthermore, Tan et al. [19] proposed the construction of a composite wall referred to as the "flexible and hard" for conditions reflecting hard roof compaction and rapid subsidence. Additionally, Wang et al. [20] established a soft-hard backfill wall structure mechanical model via theoretical analysis, physical testing, and numerical simulation. Moreover, Deng et al. [21] introduced an ordinary concrete pumping method for roadside filling to complete the roadway along the working face of medium-thick coal seams. In addition, Su et al. [22] proposed a top coal roof support technology involving high strength prestressed bolts and cable-stayed support filled with high strength materials. Based on the short cantilever beam theory, Yang et al. [23,24] suggested pre-fracturing of the entry roof from the gob roof via orientated blasting. Additionally, Wang et al. [25] proposed a mining technology for releasing pressure through directional roof cutting, with simultaneous roadway formation by increasing ground pressure and expanding rock breaking. Yang et al. [26] used numerical simulation method to analyze the influence of mining disturbance of adjacent working face on the stability of side-stepped roadway. Zhang et al. [27] established the numerical simulation of support by discrete element method and proved the support effect of roadway along goaf side. Sun et al. [28] predicted and evaluated the deformation and failure of gob-side entry retaining via numerical simulation.

Although studies on gob-side entry retaining are common and have obtained important results, the most commonly constructed roadway sides include the grouting concrete wall method and the paste filling method. The former method, however, involves the use of a rigid supporting roof, and thereby exerts a shear failure effect on the roof. This effect can promote compressive stress accumulation in the roof, leading to continuous or wall support instability. Therefore, consistently using the single hydraulic prop for support strengthening to avoid potential safety hazards is necessary [29-31]. Conversely, although the paste filling method does not produce a rigid support roof, the technology is complex and a considerable amount of paste materials are needed during construction. Therefore, the purpose of this study is to present a gob-side entry retaining technology that satisfies the requirements of a non-rigid support, ensures stability of the wall, and maintains production speed.

In this study, first, the overburden movement characteristics are described and the support resistance calculation is presented. Then, the gob-side entry retaining method with filling material for wall construction including the material bag preparation and wall construction is introduced. This is followed by a description of the underground field testing conducted using the new technology and an analysis of the obtained results. Finally, we discuss the applications of the proposed technology and present our conclusions. The proposed technology is expected to contribute to the promotion of gob-side entry retaining development.

\section{Gob-Side Entry Support Resistance Calculation}

According to the roadway side support mechanism, a mechanical model for the interaction between the roadway side support and the roof was established [32], as depicted in Figure 1.

The mechanical equations for blocks $\mathrm{AB}$ and $\mathrm{BC}$ were established by an equilibrium method to obtain the following equation:

$$
\begin{aligned}
P_{q}= & {\left[M_{L}+\left(N_{C}+q \cos \alpha \bullet e\right)\left(x_{0}+c+d\right)+\frac{1}{2}\left(q+q_{0}\right) \cos \alpha \bullet\left(x_{0}+c+d\right)^{2}-\int_{0}^{x_{0}} \sigma_{y}\left(x_{0}-x\right) d x\right.} \\
& \left.-\left(T_{C}+q \sin \alpha \bullet e\right)\left(h-\Delta S_{B}\right)-M_{0}-q \sin \alpha\left(x_{0}+c+d\right) \bullet\left(\frac{h}{2}-\Delta S_{B}\right)\right] /\left(x_{0}+c+\frac{d}{2}\right)
\end{aligned}
$$

where $\alpha$ represents the dip angle $\left(^{\circ}\right)$ of the coal seam, $c$ is the roadway width $(\mathrm{m}), d$ denotes the roadway side filling support width (m), $h$ is the basic top rock thickness $(\mathrm{m})$, and $P_{q}$ represents the roof bearing capacity of the roadway side support $(\mathrm{kN})$. The parameter $M_{L}$ is the ultimate bending moment of the basic roof strata $(\mathrm{kN} \cdot \mathrm{m}), M_{0}$ denotes the A-end of the basic top residual bending moment $(\mathrm{kN} \cdot \mathrm{m})$, $q$ represents the weight per unit length of the basic roof and its upper soft rock $(\mathrm{kN}), q_{0}$ is the dead weight per unit length of the direct roof $(\mathrm{kN}), x_{0}$ denotes the width of the plastic zone of coal beside the roadway $(\mathrm{m}), k$ represents stress concentration factor, $\sigma$ represents tensile strength of basic roof 
strata (MPa), and $\sigma_{\mathrm{y}}$ is the support strength of the coal body to the roof in the plastic zone beside the roadway $(\mathrm{MPa})$. The parameter $\Delta S_{B}$ represents the settlement at the front end of the basic roof caving $\mathrm{B}$, and it is calculated using the following expression:

$$
\Delta S_{C}=\frac{x_{0}+c+d+e}{x_{0}+c+d} \cdot \Delta S_{B}
$$

where $e$ is the length of the $\mathrm{BC}$ block (m). The parameter is then calculated from the equation given as:

$$
e=\frac{2 b}{17} \bullet \frac{b}{L_{m}} \cdot \sqrt{100+102\left(\frac{L_{m}}{b}\right)^{2}}-x_{0}-c-d
$$

where $L_{m}$ is the working face length $(\mathrm{m})$ and $b$ represents the basic jacking step distance $(\mathrm{m})$.

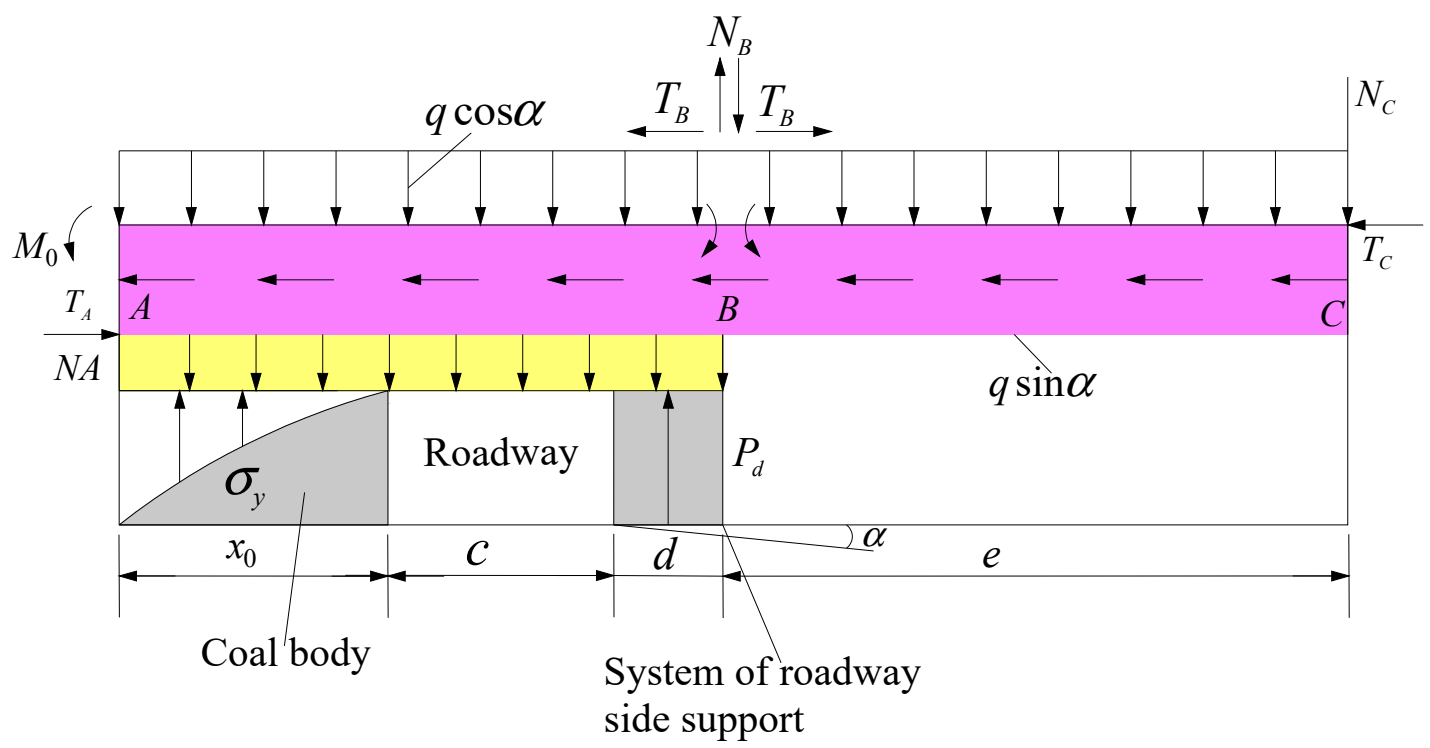

Figure 1. Basic roof mechanical model of gob-side entry retaining.

According to the field conditions of the 8101 working face of a mine, the relevant geomechanical parameters are as follows: coal seam mining height of $1.6 \mathrm{~m}$, a working face length of $230 \mathrm{~m}$, a periodic weighting length of $15 \mathrm{~m}$, and a maximum burial working face depth of $234 \mathrm{~m}$. Additionally, the basic top layer thickness was $6 \mathrm{~m}$, with a direct roof average thickness of $6 \mathrm{~m}$, and an overlying strata unit weight of $25 \mathrm{kN} / \mathrm{m}^{3}$. The other parameters are shown in Table 1 . To simplify the calculation while considering the safety factor, the residual bending moment of the rock beam at both ends of rock block $\mathrm{B}$ was taken as 0 . After calculation, the average demand strength of the filling body was $2.63 \mathrm{MPa}$. Considering a safety factor of 1.5 , the strength of the filling body required for filling the roadway was determined as roughly $4 \mathrm{MPa}$.

Table 1. Other parameters.

\begin{tabular}{ccccc}
\hline Parameters & $\sigma / \mathbf{M P a}$ & $\mathbf{k}$ & $\alpha /{ }^{\circ}$ & $\sigma_{y} / \mathbf{M P a}$ \\
\hline Value & 6 & 2.0 & 3 & 4.15 \\
\hline
\end{tabular}

\section{Gob-Side Entry Retaining Mining Technology with Bag Filling Material for Wall Construction}

\subsection{Bag Preparation}

\subsubsection{Raw Materials}

The bag material comprises the No. 1 and No. 2 components and an additive described as follows: 
1. Cement-It is the most important material for gob-side entry retaining. It hydrates immediately on encountering water and initially forms a plastic paste, with the paste gradually losing its plasticity. The cement paste then hardens, thereby forming $2 \mathrm{CaoSiO}_{2} \cdot \mathrm{nH}_{2} \mathrm{O}$, and the strength increases until it attains a desired condensate value.

2. Putty powder-It is mainly a binder that enables aggregation and firm bonding of concrete particles. It also prevents hollowing, micro expansion, and cracking when the filling material encounters water. It is characterized by small and cohesive particles.

3. Sand-This contains mainly $\mathrm{SiO}_{2}$, representing an inert material of high strength and good durability. It is a good low-cost fine aggregate that acts as "bone", and improves the overall strength of the mixed material.

4. Fly ash-It comprises particles with sizes of 1-100 $\mu \mathrm{m}$ from coal combustion. Its characteristics involve specific corrosion resistance and high early strength. In the mixed material used for gob-side entry retaining, it helps to increase the workability and overall strength of the mixed material.

5. Additive-The accelerator is a high efficiency additive commonly used in coal mine enterprises. It is an admixture that increases the initial speed of the reaction between cement and water, and promotes the quick setting and hardening of the concrete.

\subsubsection{Material Ratio and Bag Preparation}

The mixing ratio of cement and putty powder in group 1 was $3: 1$, while that of sand and fly ash in group 2 was 3:2, and the ratio of group 1 to group 2 was 1:1, with $1.2 \%$ of the accelerator. The mixing ratio was obtained based on an orthogonal experiment. A batching and a mixing plant were built at the mine site, incorporating rain- and moisture-proof measures. According to the designed proportioning scheme, the base materials and additive were combined, mixed, dried, and stored in a storage tank. The additive was then measured based on the bag quantity using an electronic scale, and then manually loaded into a screw feeder for transportation, and mixed using a powder mixer. After mixing, the dried materials were transferred to a sub-loading workshop, and the evenly stirred, dried materials were placed in bags measuring $730 \mathrm{~mm} \times 500 \mathrm{~mm}$.

\subsubsection{Mechanical Properties of the Materials}

Based on the previously stated material ratios, the prepared samples were poured into cube molds with size of $70.7 \mathrm{~mm} \times 70.7 \mathrm{~mm} \times 70.7 \mathrm{~mm}$ Then, the samples were placed in a constant humidity box with a temperature of $20^{\circ} \mathrm{C}$. Finally, according to the Chinese concrete test standard (GB/T 50107-2010), the uniaxial compressive strength of specimens cured for 3, 7 and 28 days were tested respectively $[33,34]$. The experimental process is shown in Figure 2. The uniaxial compressive strength was commonly used for evaluating the mechanical properties of materials [35-41]. The mechanical properties of the samples were determined by a Shimazu AG-X250 electronic universal testing machine. In the testing, the loading mode of a sample was controlled by the displacement, at a loading rate of $0.01 \mathrm{~mm} / \mathrm{s}$.

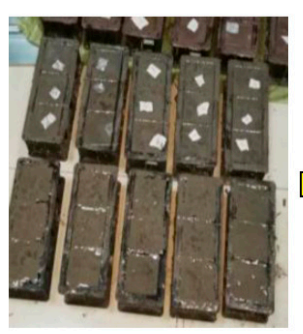

(a)

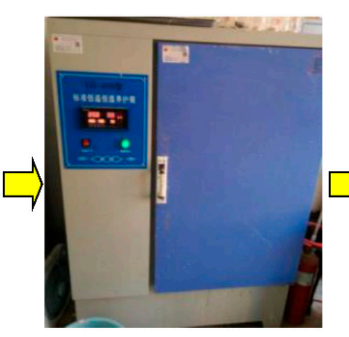

(b)

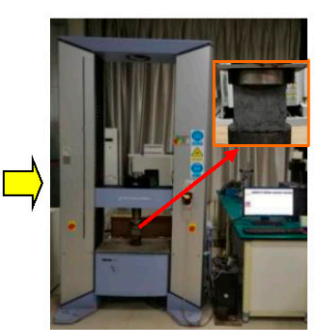

(c)

Figure 2. Photos of the experimental process showing (a) samples, (b) the standard curing box, and (c) the electronic compression testing machine. 
For a complete analysis of the strength of the support at different curing ages, uniaxial compressive strength tests were conducted, and the results are shown in Figure 3.

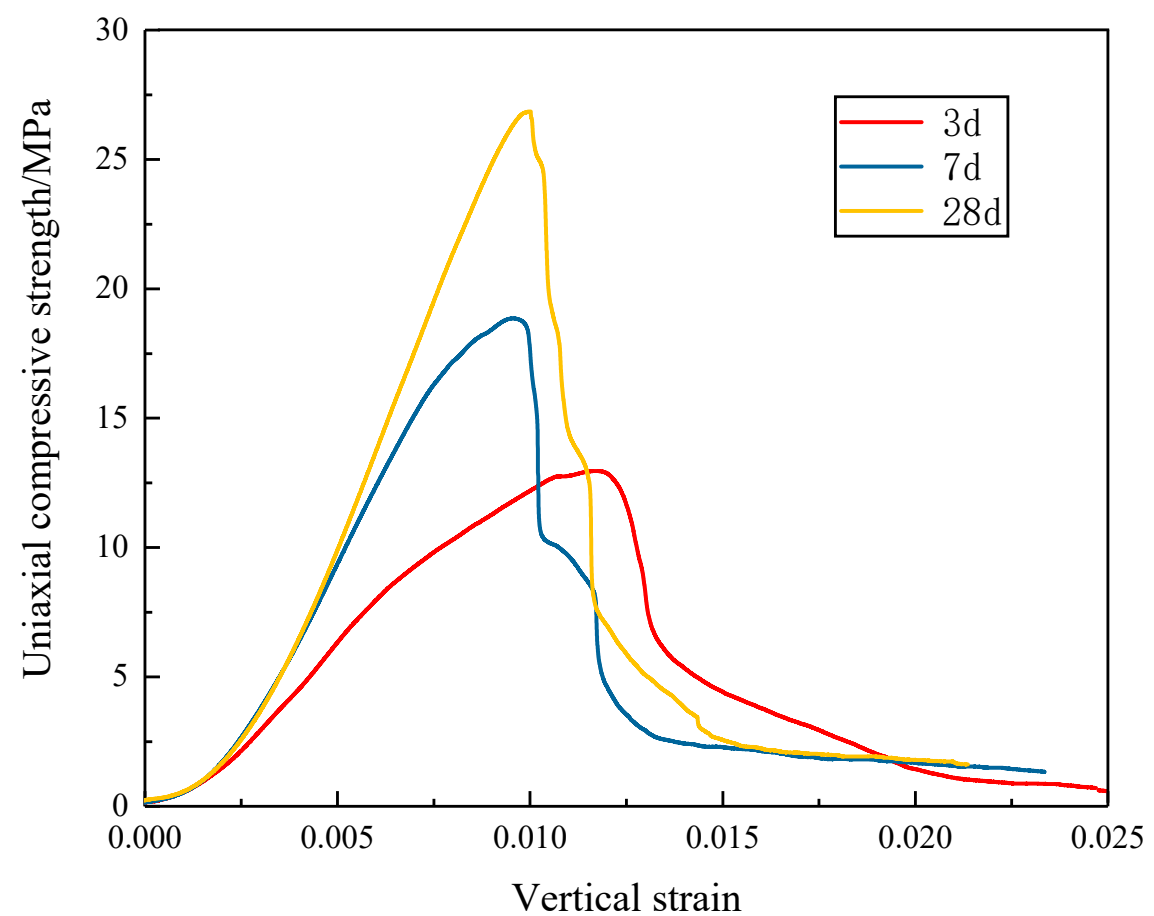

(a)

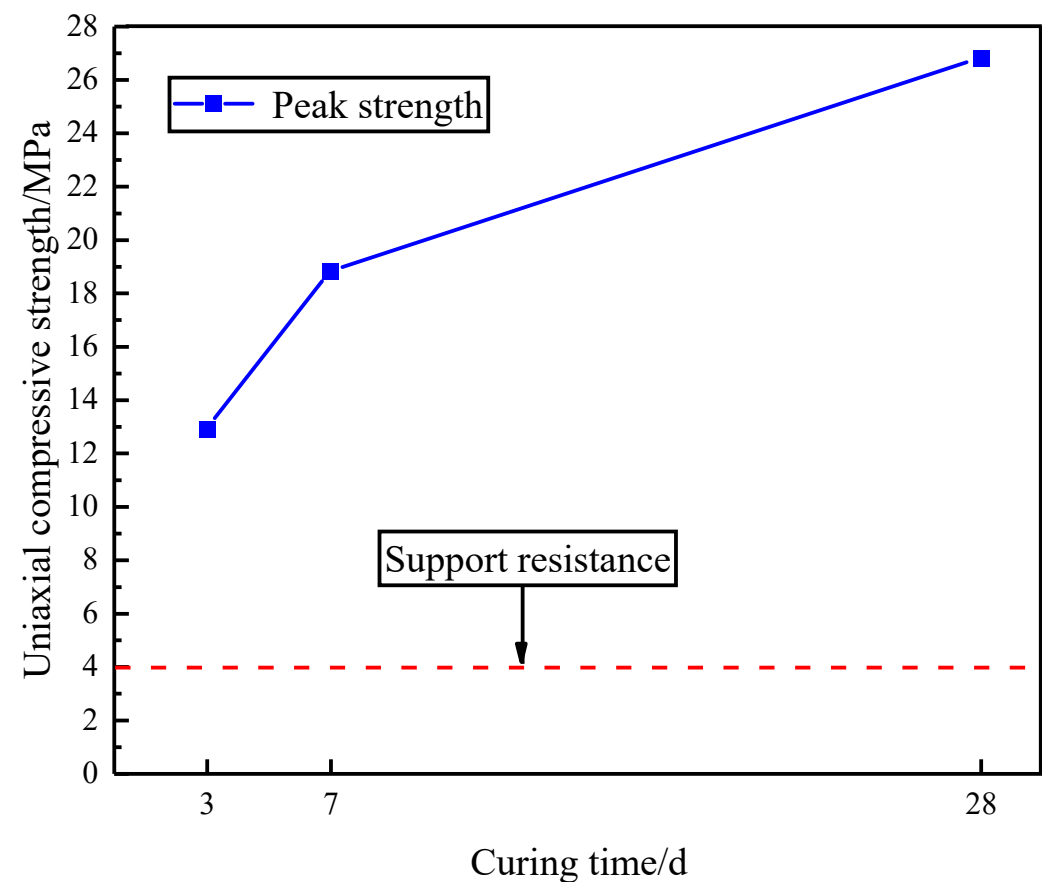

(b)

Figure 3. Mechanical property plots showing (a) stress-strain curves for samples cured for 3, 7 and 28 days and (b) the strength of specimens at different curing ages. 
The stress-strain curves for specimens with different curing times (3, 7 and 28 days) are displayed in Figure 3a. The curves reveal that the samples have undergone the compaction, elastic, fracturing, and failure stages. The elasticity moduli for the samples cured for 3, 7 and 28 days are 1.55, 2.95, and $3.52 \mathrm{GPa}$, respectively. The deformation resistance of the support increases with increasing curing age. From Figure 3b, the peak strengths of the samples cured for 3, 7 and 28 days are 12.91, 18.82, and $26.84 \mathrm{MPa}$, respectively. The initial sample strength largely exceeds the required support strength, thereby indicating that the bagged material satisfies the gob-side entry retaining production demands.

\subsection{Wall Construction}

The gob-side entry retaining method is regarded as an independent system for production organization and management [42,43]; its components are depicted in Figure 4.

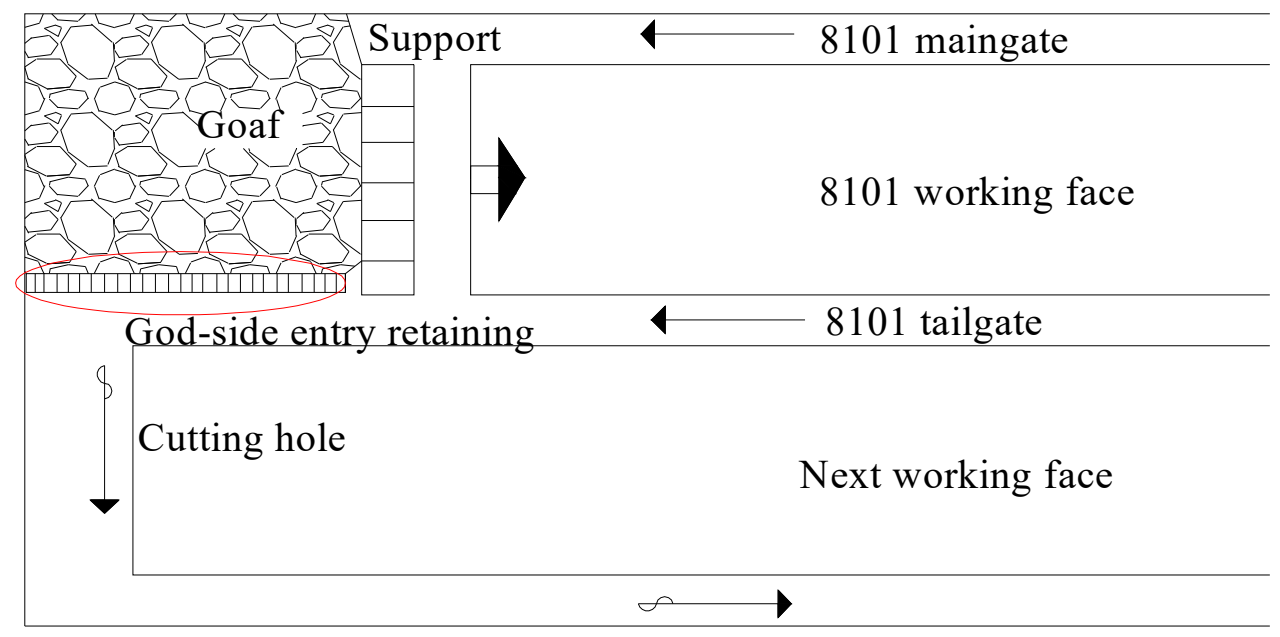

Figure 4. Schematic of the gob-side entry retaining system.

Considering that the 8101 working face is a thin coal seam and to ensure stability of the walls, the bag positions must be on a plane vertical to the underlying layer from coal cutting during field construction. The construction requires an upper narrow and lower wide layer pattern along the roadway's central axis. The steps involved in the wall construction are summarized as follows.

First, the prepared material bags were transported from the surface to the subsurface. According to the designed position of the reserved roadway and the thickness of the constructed roadway side, the bags were pushed along the working face. After the end hydraulic support, along with mining of the working face, a wall was built to the roof with material bags, and then advanced by pushing forward, using stacking as the building method. The material bags were then tightly pressed and stacked layer by layer. When placing a layer of bags horizontally, a custom-made water injection gun was used for spraying water to evenly wet the bags. This enabled wetting of the water hardening material until solidification, thereby ensuring an effective initial support strength within the shortest time. To improve the stability of the bagged wall, bolts and steel strips were used for support. Concurrently, a composite hydraulic prop was employed as a temporary supplementary support during the construction. After the wall attained an initial support strength, the hydraulic prop was moved forward sequentially until the construction was complete. The structure of the constructed wall is depicted in Figure 5. 


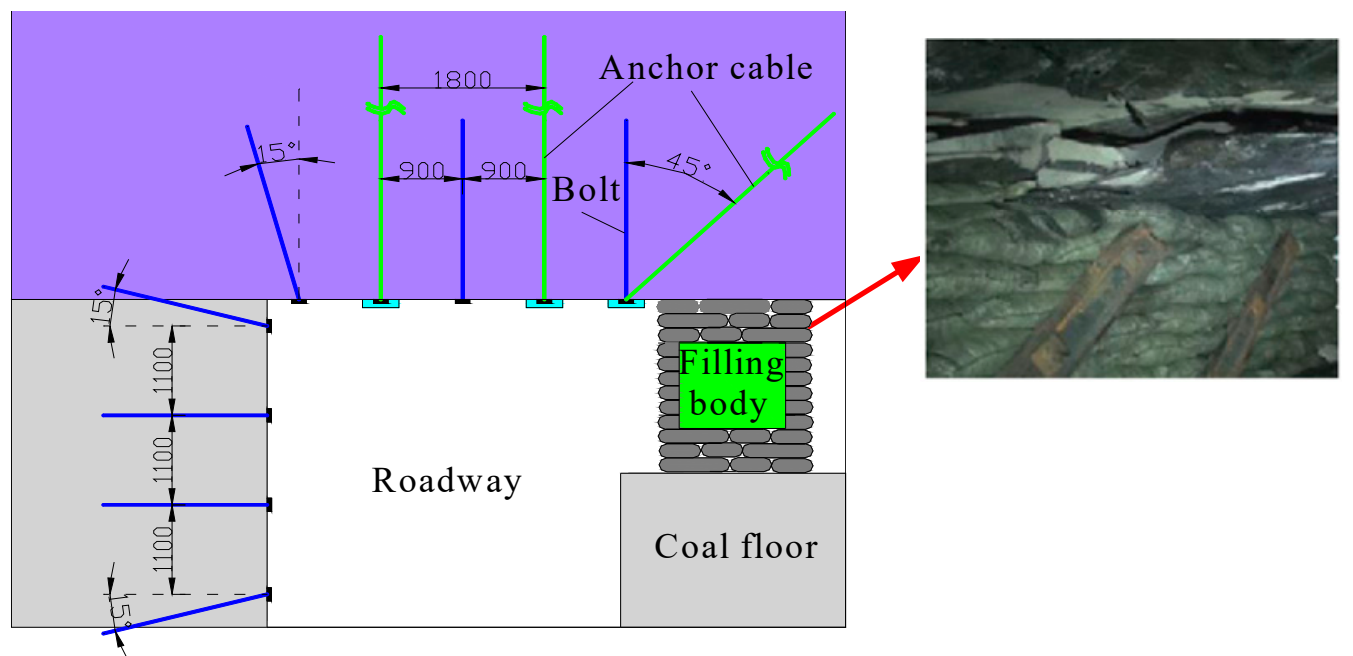

Figure 5. Schematic of a wall construction displaying the filling body relative to the coal floor and roadway.

\section{Numerical Simulation and Field Monitoring}

\subsection{Numerical Simulation}

Based on geological conditions of the 8101 working face, a numerical simulation was performed for gob-side entry retaining. The simulation enabled the analysis of the conditions in the roof, floor, and sides of the roadway. The mechanical parameters of the model are shown in Table 2.

\subsubsection{Displacement along the Two Sides of the Roadway}

As the working face was moved over different distances $(5,10,20,40,60$ and $80 \mathrm{~m})$, the movements along the horizontal direction ( $x$-axis) were monitored, and the corresponding displacements are depicted in Figure 6.

Similarly, monitoring was conducted at $30 \mathrm{~m}$ in front of the working face, with the results displayed in Figure 7.

Figures 6 and 7 reveal that the displacement of the coal body is larger than that of the support, with the entire deformation dominantly associated with the coal body. It is mainly because the strength of the support is greater than that of the coal body, with the coal body being prone to plastic damage and flow. At the corner of the roadway, especially, the support should be strengthened. At the corner of the roadway, especially, the support should be strengthened. From the beginning of monitoring to when the working face was pushed beyond $20 \mathrm{~m}$ from the monitoring point, the support exhibits an increasing trend with regard to displacement; when the working face exceeds $20 \mathrm{~m}$ from the monitoring point, the area around the support body is essentially stable. This demonstrates that the action of the rock beam on the support body remains constant after the working face attains stability. The displacement on the coal body side, however, increases rapidly in the early stage, stabilizes in the middle stage, and maintains the stability during the late stage. 
Table 2. Mechanical parameters of model.

\begin{tabular}{|c|c|c|c|c|c|c|c|}
\hline & Name & $\begin{array}{c}\text { Bulk } \\
\text { Density } / \mathbf{k N} / \mathbf{m}^{3}\end{array}$ & $\begin{array}{c}\text { Shear } \\
\text { Modulus/GPa }\end{array}$ & $\begin{array}{c}\text { Bulk } \\
\text { Modulus/GPa }\end{array}$ & Cohesion/MPa & $\begin{array}{c}\text { Tensile } \\
\text { Strength/MPa }\end{array}$ & $\begin{array}{c}\text { Internal Friction } \\
\text { Angle/ }{ }^{\circ}\end{array}$ \\
\hline \multirow{4}{*}{ Roof } & Siltstone & 27.1 & 0.35 & 0.77 & 7.8 & 9.3 & 32 \\
\hline & Sandy mudstone & 25.6 & 0.24 & 0.45 & 3.6 & 2.4 & 25 \\
\hline & Medium sandstone & 26.2 & 0.29 & 0.49 & 5.2 & 5.1 & 28 \\
\hline & Sandy mudstone & 25.3 & 0.24 & 0.45 & 3.6 & 2.4 & 25 \\
\hline Coal & Coal & 13.1 & 0.13 & 0.41 & 2.5 & 1.1 & 17 \\
\hline \multirow{3}{*}{ Floor } & Sandy mudstone & 25.3 & 0.24 & 0.45 & 3.6 & 2.4 & 25 \\
\hline & Medium sandstone & 26.2 & 0.29 & 0.49 & 5.2 & 5.1 & 28 \\
\hline & Filling body & 25.0 & 0.95 & 0.71 & 4.4 & 3.5 & 50 \\
\hline
\end{tabular}




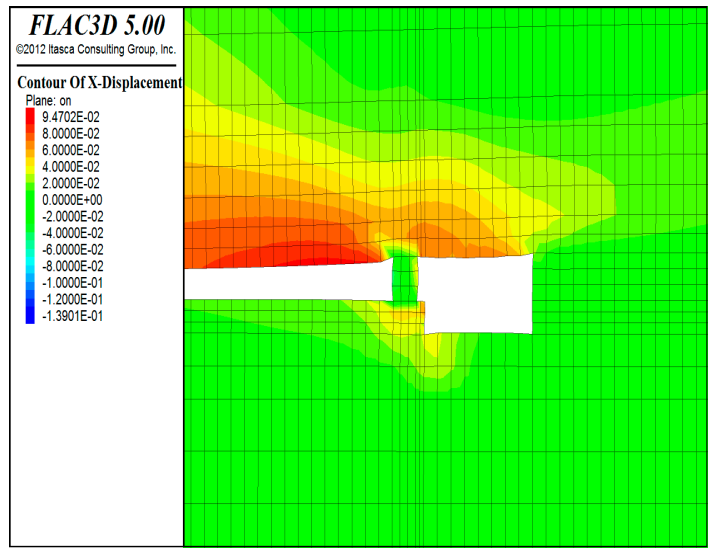

(a)

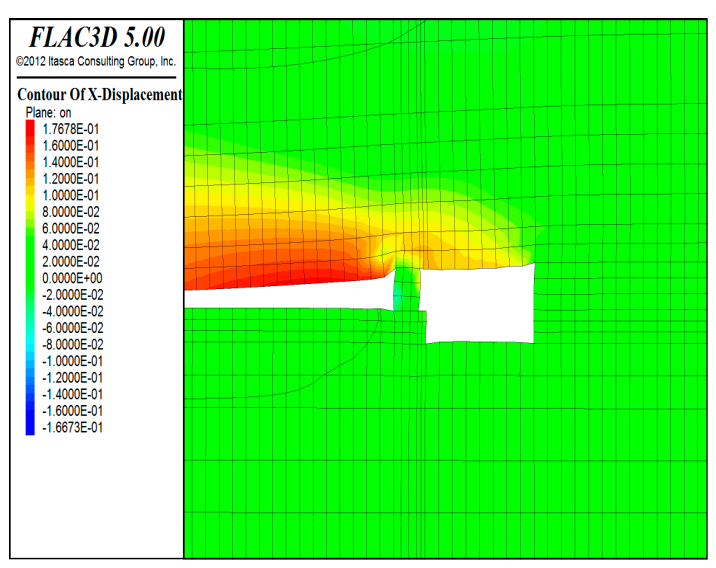

(c)

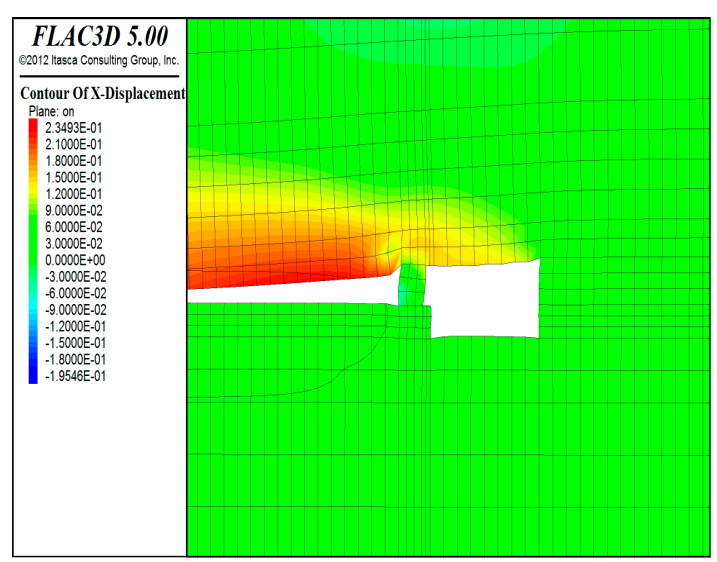

(e)

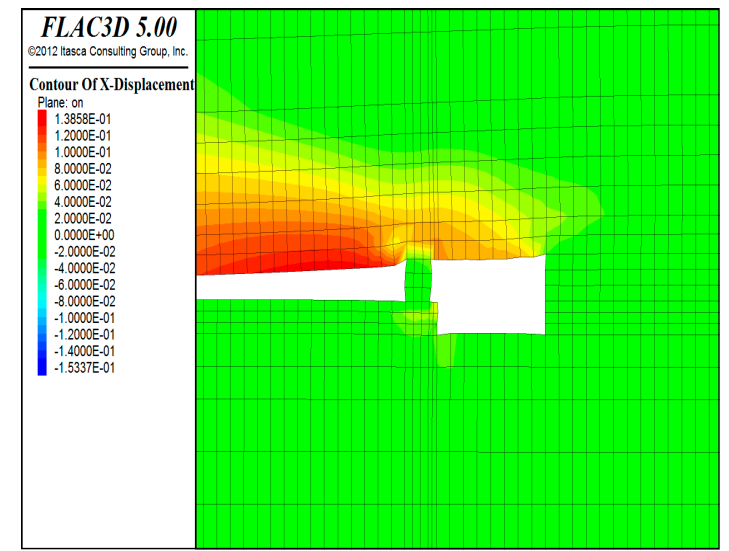

(b)

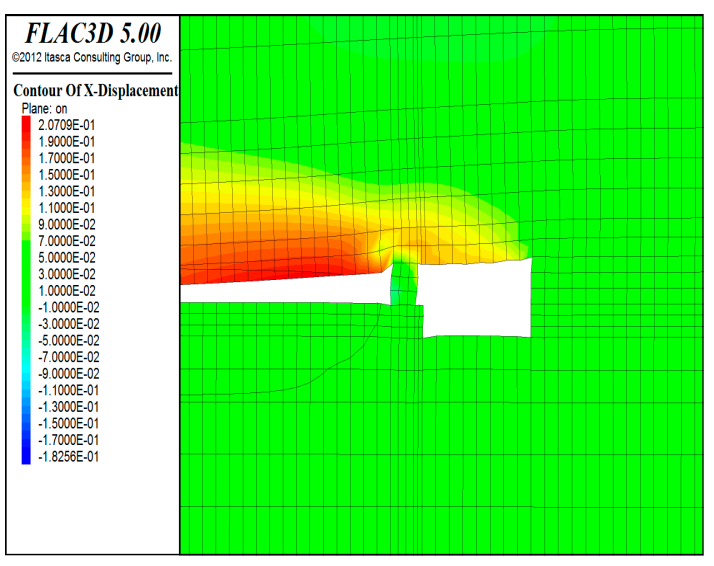

(d)

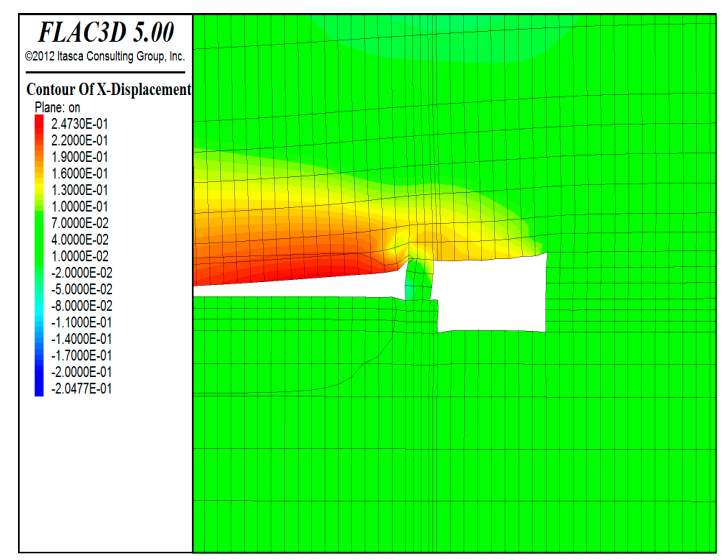

(f)

Figure 6. Changes in the horizontal displacement with the working face pushed to (a) 5, (b) 10, (c) 20, (d) 40, (e) 60, and (f) $80 \mathrm{~m}$. 


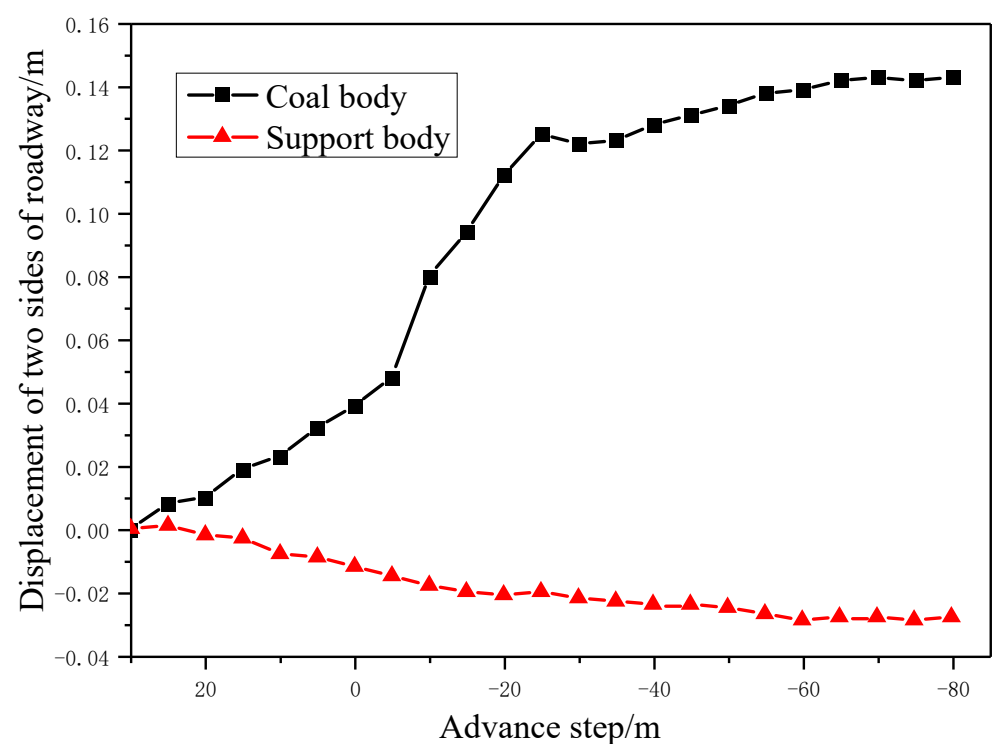

Figure 7. Displacement along the two sides of the roadways.

\subsubsection{Vertical Displacement}

According to Figure 8, the area with the largest vertical displacement is above the goaf, followed by the area near the top layer above the support body.

Displacement curves of the top and bottom plates as well as the advancing working face change are shown in Figure 9.

The data presented in Figure 9 show that when the advancing step of the working face is $15 \mathrm{~m}$ (i.e., $15 \mathrm{~m}$ from the monitoring point), the displacement of the roof and floor begins to occur, owing to the influence of the advancing stress. As the working face advances to be within $5 \mathrm{~m}$ of the monitoring point, the degree of deformation of the roadway roof and floor increases. When the working face advances to $15 \mathrm{~m}$ from the monitoring point, the bottom plate deformation is stable, whereas the top plate only exhibits stability when the working face advances to $30 \mathrm{~m}$ from the monitoring point.

The roadway floor deformation is positive, whereas that of the roof is negative. As the vertical direction is set as the $z$-axis square during model construction, the floor displacement actually represents the displacement of the center of the roadway floor, that is, the floor heave. The maximum floor heave is $98 \mathrm{~mm}$, while the center displacement (subsidence) of the roof is $180 \mathrm{~mm}$.

From the displacement curves and cloud charts, the deformation of the portions in contact for the support body, coal body, and roof are relatively high, and are mainly affected by the bearing stress. The stress and deformation in the filling body are significantly higher than those in the coal body side. This is because the support is closer to the goaf than the coal wall, and the support bears higher stress, with the floor heave also reflecting stress relief. The roof above the goaf becomes unstable during the collapse process, eventually causing sinking of the roadway roof.

Based on displacement, the junction of the roadway side support and floor changes significantly, with subsidence of the support side being significantly higher than that of the coal wall side because the support side bears a higher stress. Displacement is obvious at the center of the roadway floor, and this is mainly caused by the stress release, thereby explaining the floor heaving phenomenon. The roof of the roadway exhibits subsidence. Owing to roof rotation and subsidence, the roof at the support side is greater than that at the coal wall side. 


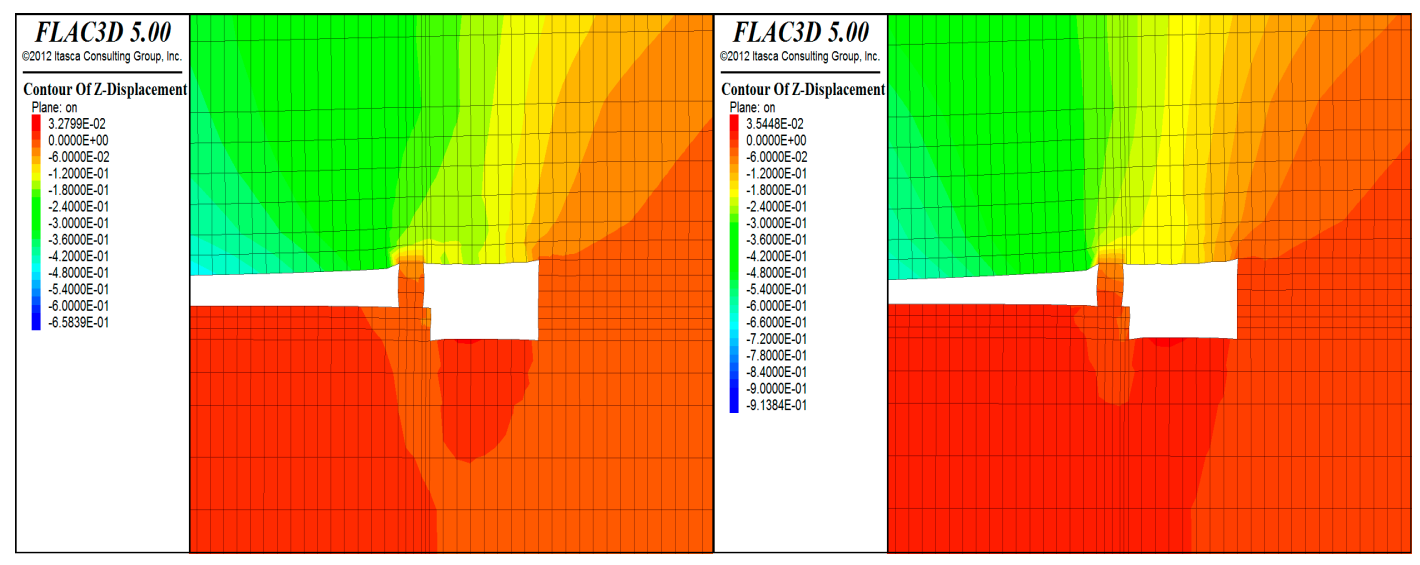

(a)

(b)

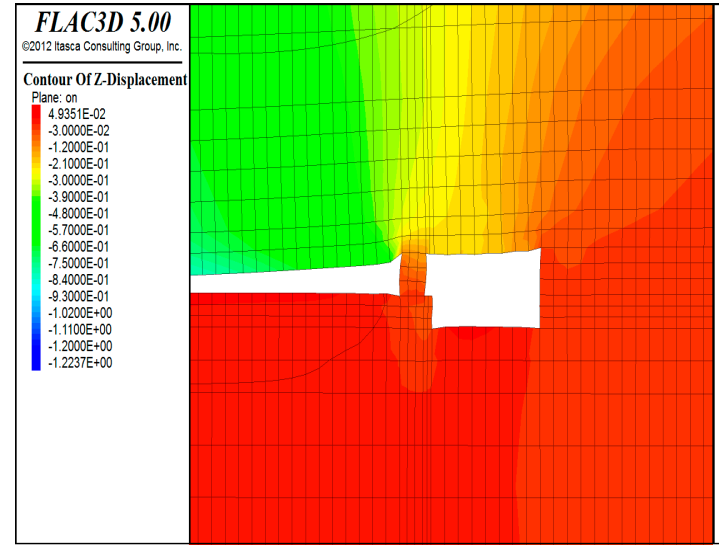

(c)

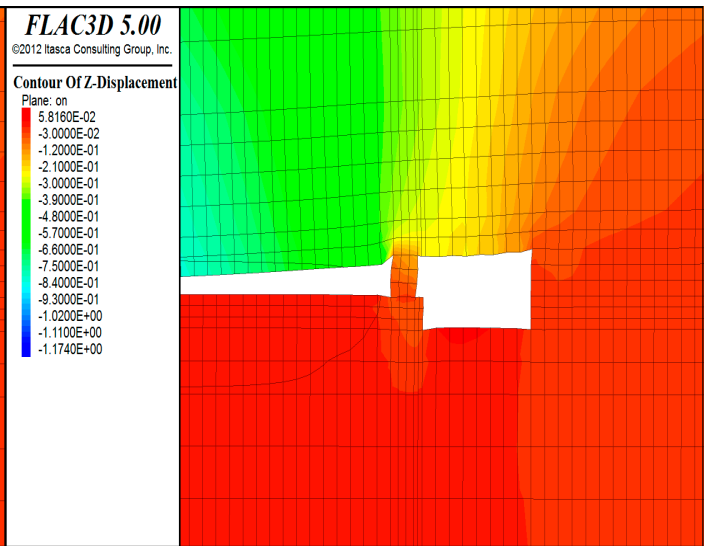

(d)

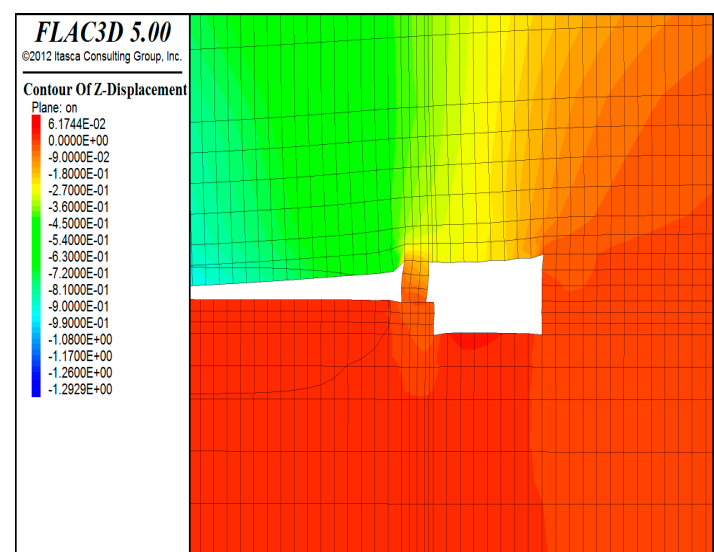

(e)

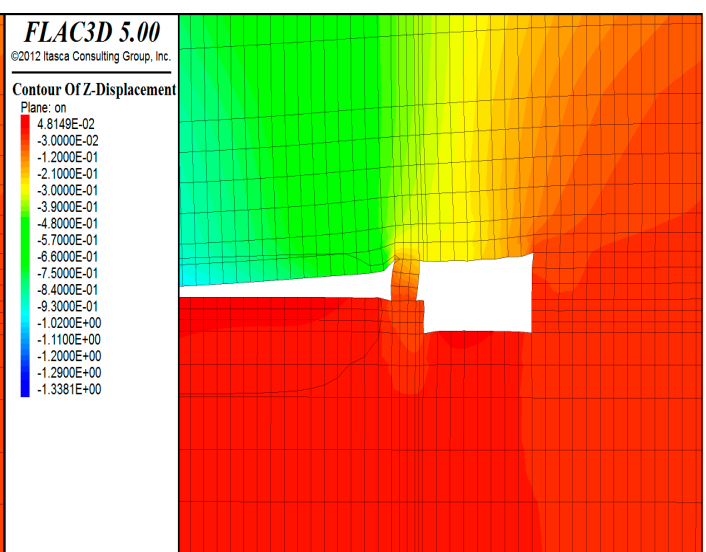

(f)

Figure 8. Vertical displacement associated with movement of the working face for (a) 5, (b) 10, (c) 20, (d) 40, (e) 60, and (f) $80 \mathrm{~m}$. 


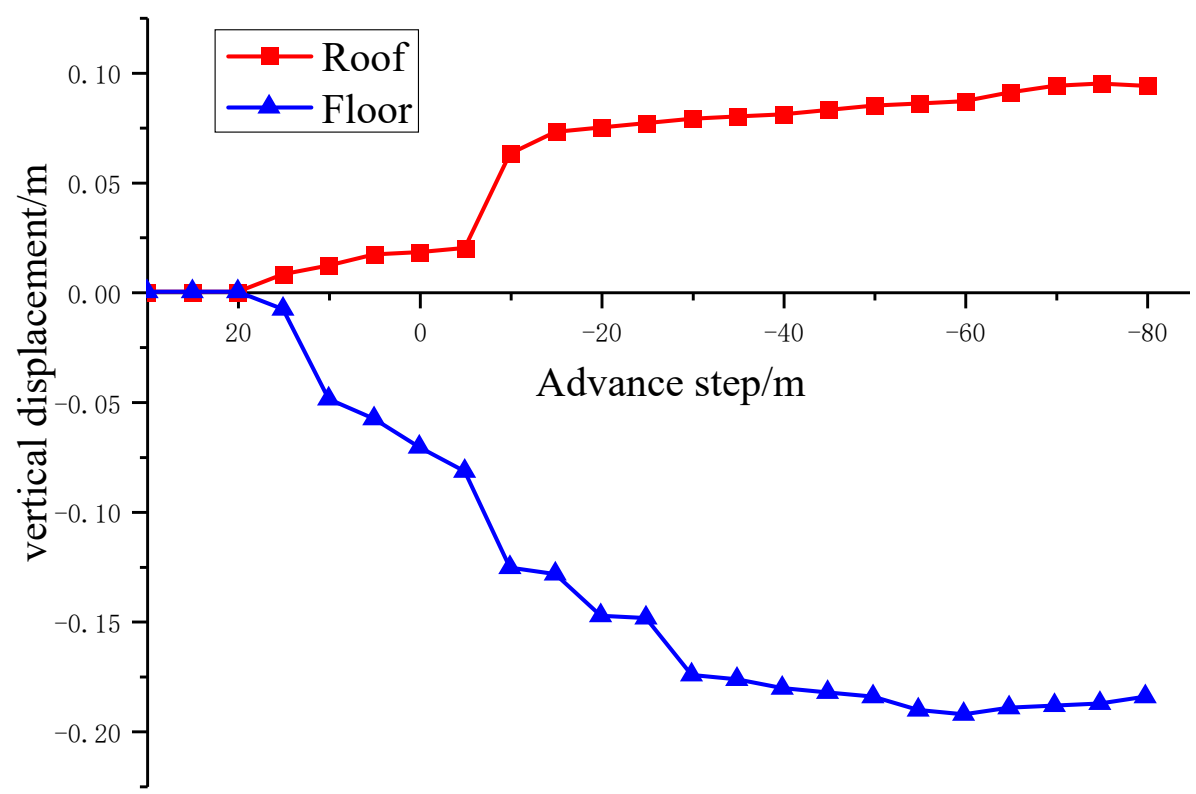

Figure 9. Vertical displacement variations along two sides of the roadway.

\subsubsection{Stress Conditions at the Roof and Floor of the Support Body}

In the numerical simulation, the stress monitoring points were set at the upper and lower positions (top and bottom plates) of the support body, $30 \mathrm{~m}$ away from the working face, to monitor the vertical stresses on the left and right sides of the support body and subsequently analyze the support effects and stress changes. Some of the observations from this analysis are illustrated in Figure 10.

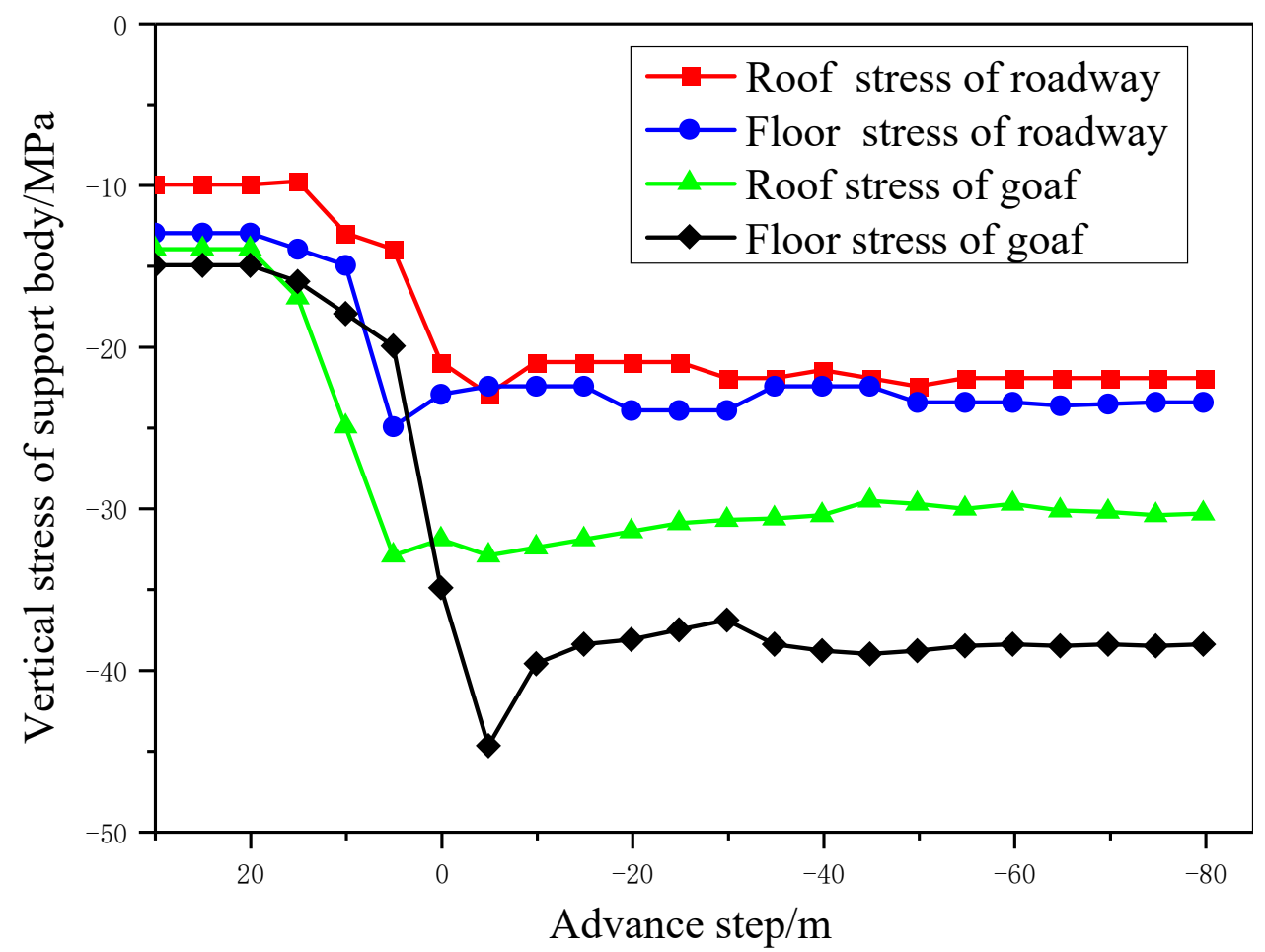

Figure 10. Vertical stress against displacement for the top and bottom sides of the support body. 
Data in Figure 10 shows that when the advance step of the working face is less than $30 \mathrm{~m}$, the position of the support body is in the originally completed roadway, with a side hosting the coal body of the previous working face, while the other side is the roadway space. The stress distribution and surrounding rock deformation are similar to those of the next working face, characterized by a symmetrical distribution. However, as the working face advances, after displacement to $30 \mathrm{~m}$ (the position of the monitoring point), construction of the support body began, and the support body was utilized instead of the coal pillar. As the coal near the support body was mined, the stress on the support body was higher than that on the raw coal for the same width. Therefore, the peak vertical stress on the support is higher than that of the advanced support, and this is caused by movement of the roadway roof. From the change curves, the maximum stress value on the floor outside the support (near the goaf side) is $45 \mathrm{MPa}$, which is approximately 1.8 times the peak support stress value inside the roadway (near the coal side), and approximately 3.5 times the initial stress (15 MPa), with subsequent rapid decrease. When the working face advances for more than $5 \mathrm{~m}$ from the monitoring point, the stress slowly decreases and stabilizes. Conversely, when the working face advances to $15 \mathrm{~m}$, the vertical stress on the roadway floor side starts decreasing, continuing to drop until $5 \mathrm{~m}$ from the monitoring point, and dropping by $21 \mathrm{MPa}$ (roughly 1.9 times the original), followed by a more gradual decrease and then stability.

The stress outside the support (near the goaf side) is much higher than that at the roadway side (coal wall), and this is attributed to the rotation and sinking of the roof above the support. Precisely, the stress at the goaf side of the support is approximately 1.4 times that of the roadway side roof.

\subsection{Field Monitoring}

Field monitoring was conducted to better understand the effect of gob-side entry retaining involving the use of bag filling material for building an 8101 working face, especially the roof movement after gob-side entry retaining. The parameters and structures monitored were the single hydraulic prop, roof separation layer, bolt stress condition, and displacement on two sides of the roadway, the roof, and floor. The test equipment is shown in Figure 11.

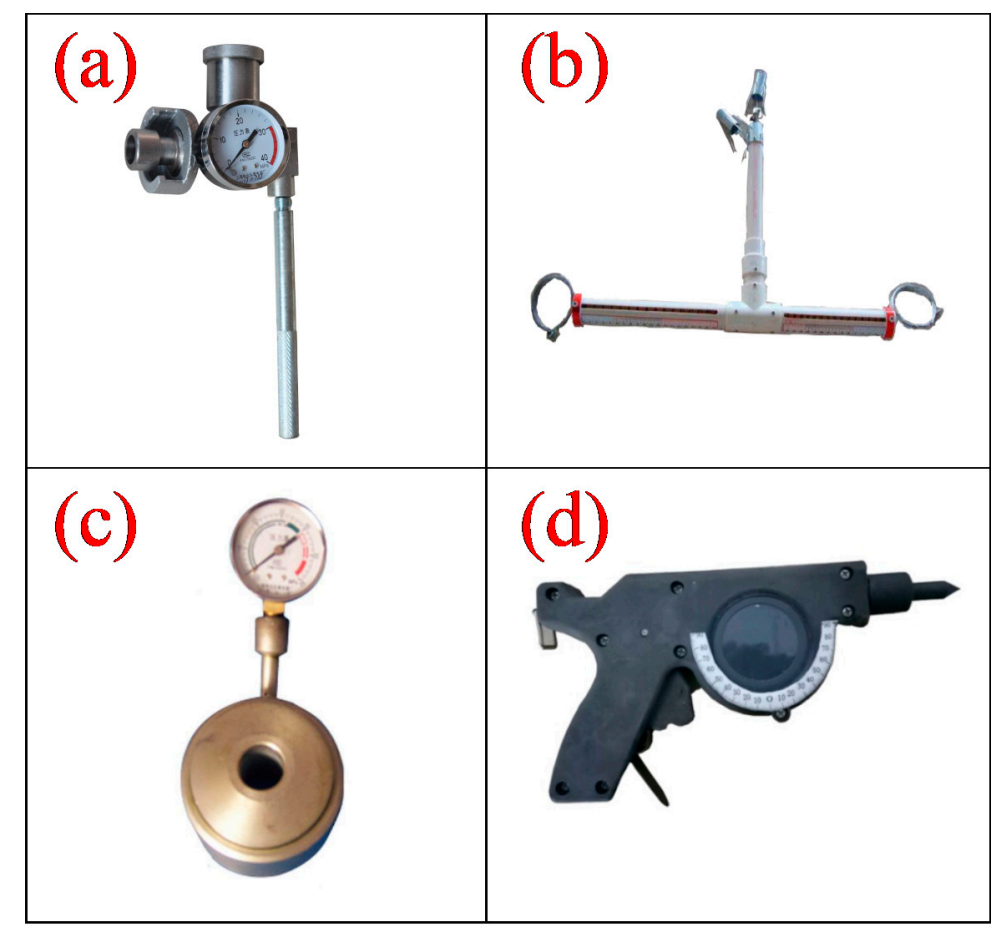

Figure 11. Test equipment: (a) single pillar dynamometer, (b) roof separation instrument, (c) bolt dynamometer and $(\mathbf{d})$ measuring gun. 


\subsubsection{Single Hydraulic Prop Monitoring Analysis}

As the working face advances, the stress ahead of the roadway gradually becomes concentrated, with, especially, the basic roof beam reaching its maximum before breaking. Two stress fields emerge after the basic roof rock beam breaks, and both are verifiable by the single hydraulic prop of the advancing support. Therefore, 14 observation points with $2 \mathrm{~m}$ separation were arranged within $30 \mathrm{~m}$ of the advancing support. According to data from an observation point $30 \mathrm{~m}$ from the working face, the load of the single hydraulic prop of the advancing support varies with the working face distance, and the results are displayed in Figure 12.

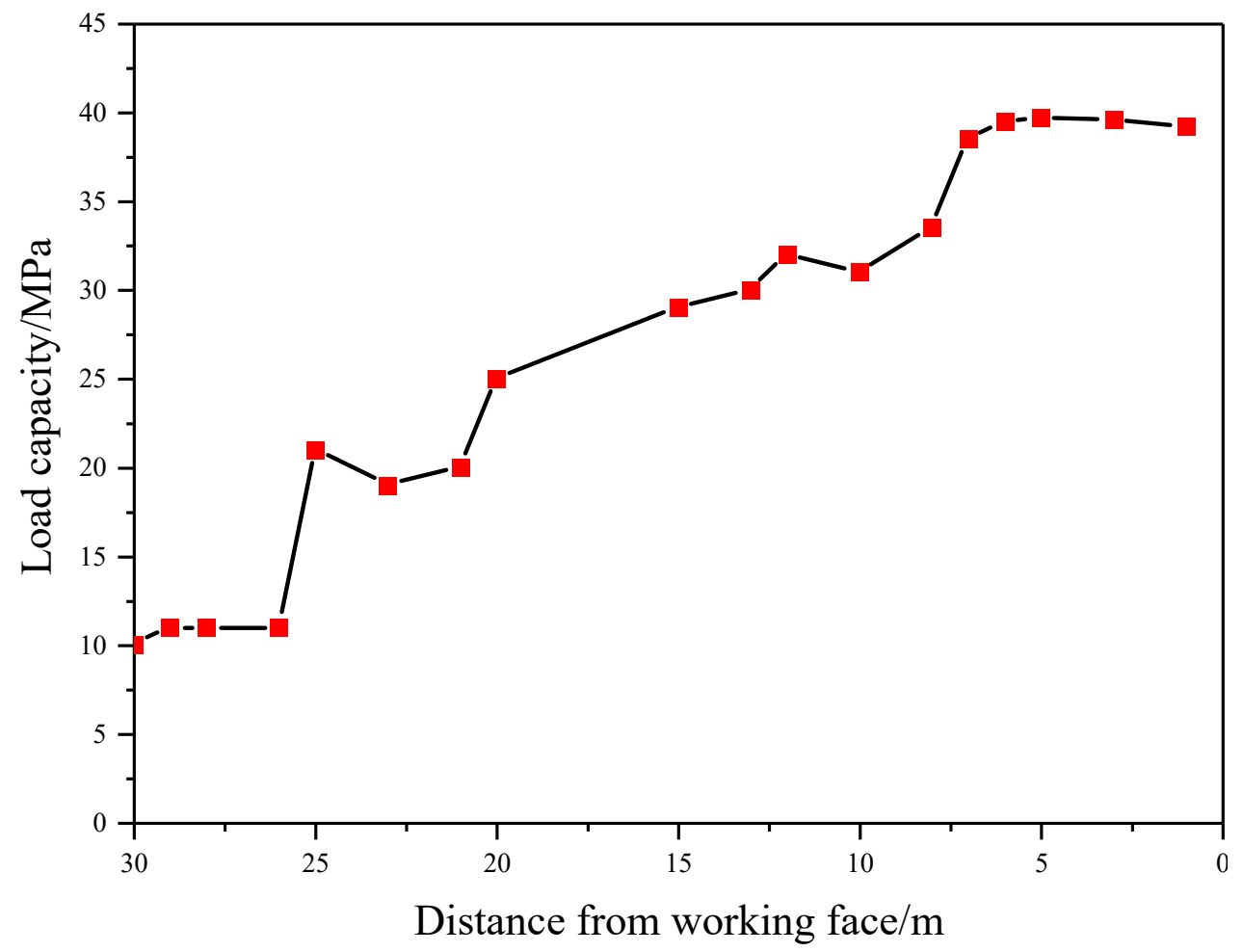

Figure 12. Monitoring chart for the single hydraulic prop.

From Figure 12, it can be observed that the advanced support load significantly increases when the measuring point is $26.5 \mathrm{~m}$ away from the working face. Furthermore, when the working face is approximately $7 \mathrm{~m}$ from the working face, the single hydraulic prop reaches the maximum value $(40 \mathrm{MPa})$. This demonstrates that the pressure at the advancing support changes significantly from $25 \mathrm{~m}$ from the working face.

\subsubsection{Roof Separation Observation Results Analysis}

A roof separation instrument was used for roof observation, primarily to analyze the changes in the mining roadway under the influence of shocks, and highlight the rationale for the roadway support $[44,45]$. A ZKBY-II (5 m) roof separation instrument was therefore installed on the roof for detecting the roof separation through processing of the collected deep base and shallow base points data of the roof separation instrument, and roof separation curves for the three sections are provided in Figure 13.

For \#1 monitoring point of the separation instrument, the separation increases rapidly when the working face advance step is $3 \mathrm{~m}$. At an advance step of $22.3 \mathrm{~m}$, the separation reaches a peak value of $44 \mathrm{~mm}$. Since \#2 and \#3 separation instrument monitoring points are far from the working face, basically no separation is observed during the initial period. When these are advanced to $12 \mathrm{~m}$ and $22 \mathrm{~m}$, respectively, the separation begins to increase, thereby producing maximum separation values of 
39 and $40 \mathrm{~mm}$, respectively. A maximum separation of $44 \mathrm{~mm}$ occurs at 5-20 $\mathrm{m}$ from the coal wall of the working face, and the separation layer is consistent with the roof pressure. Therefore, the roof separation of the roadway is small, and the roof conditions are good after the gob-side entry retaining.

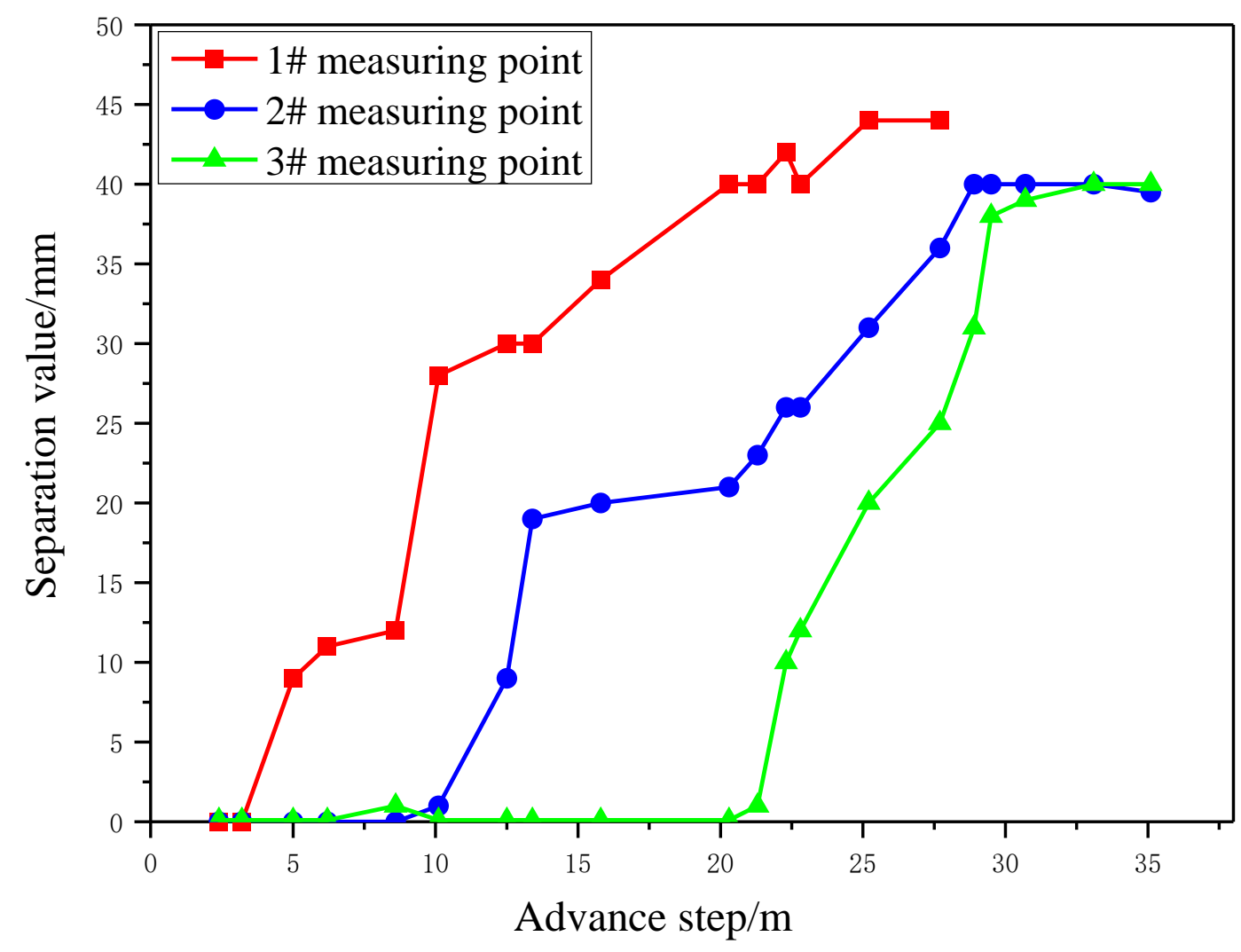

Figure 13. Curves showing the relationships between the roof separation and propelling step distance.

\subsubsection{Bolt Stress Monitoring Analysis}

ZMC-IIA hydraulic bolt dynamometers were installed on the roof and sides of the roadway for detecting the stress states and their variations. This allowed for the monitoring of the bolt stress and assessment of the associated effects [46,47]. Six bolt dynamometers, positioned at 20 and $35 \mathrm{~m}$ along the roadway track (marked as \#1 and \#2, respectively) were installed on the upper side, lower side, and roof of the section. The pressure curves for the bolt dynamometers are depicted in Figure 14.

The readings of the three dynamometers for the \#1 section basically remained unchanged before displacement to $9 \mathrm{~m}$ and remained within the range of the initial installation force. At a distance of $11 \mathrm{~m}$ from the coal wall, owing to mining influence, the dynamometer readings for the roof and the bolt dynamometer on the coal wall began to increase significantly, reaching maximum values at the coal wall. The maximum value for the roof dynamometer was $10.6 \mathrm{MPa}$, while that of the upper side was $6.6 \mathrm{MPa}$, with only a minor change in the lower side dynamometer.

There are major variations in the dynamometer readings for the upper and lower sides of section \#2 before the advance step of $15 \mathrm{~m}$. At $20 \mathrm{~m}$ from the coal wall, owing to the influence of mining, the readings for the roof and the bolt dynamometer on the coal wall begin to increase significantly, reaching maximum values at the coal wall. The maximum reading for the roof was $7.0 \mathrm{MPa}$, while that for the upper side was $6.0 \mathrm{MPa}$, with only a minor increase in the lower side dynamometer.

According to the monitoring data of the bolt dynamometer, damage and plastic deformation are not obvious in the roadway surrounding rocks, with changes present only close to the coal wall of the working face (within 5-8 m). 


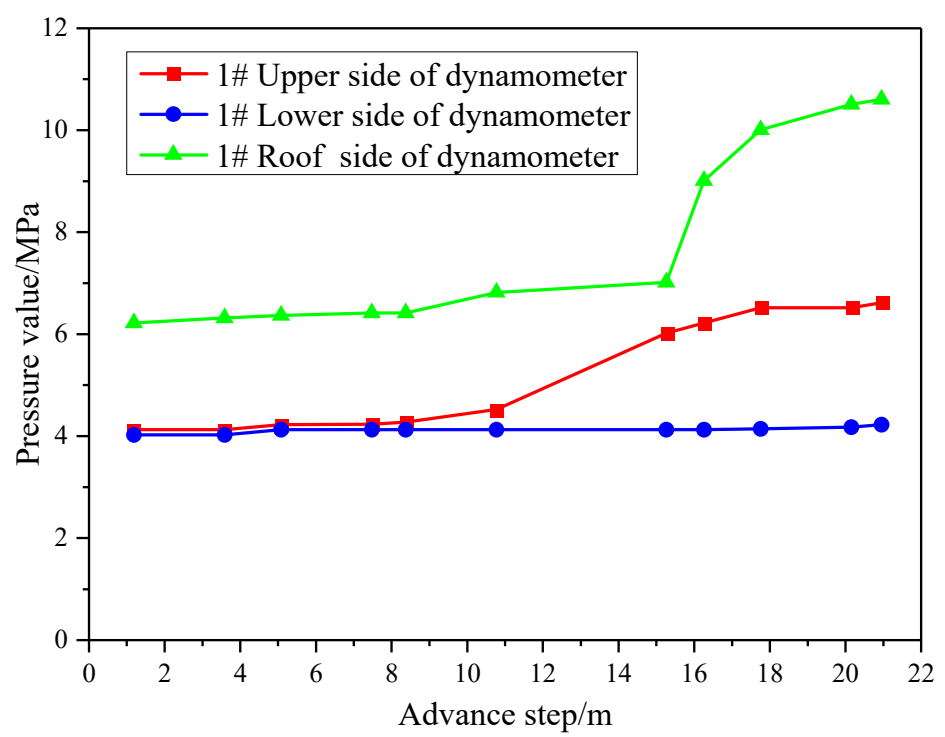

(a)

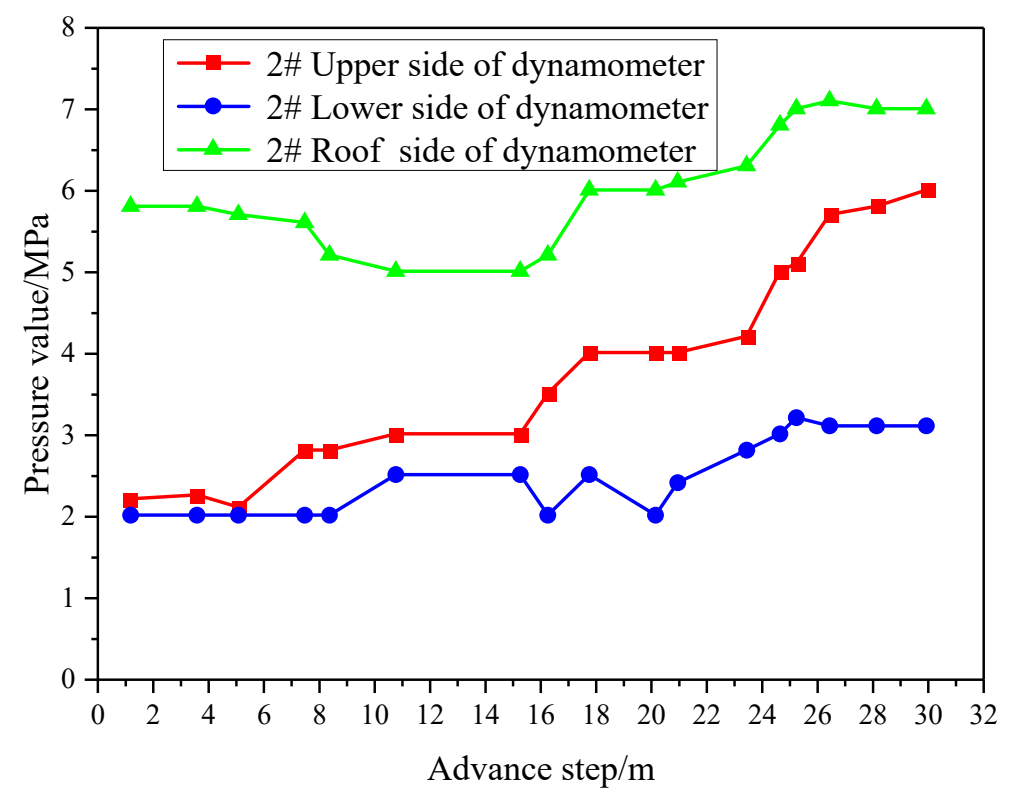

(b)

Figure 14. Stress curves for bolts at (a) \#1 monitoring point and (b) \#2 monitoring point.

\subsubsection{Analysis of Deformation on the Roadway Sides and Near the Roof and Floor}

The section that was $25 \mathrm{~m}$ from the working face was analyzed, and a cumulative deformation curve of this section is plotted in Figure 15.

At an advance step of $1 \mathrm{~m}$, it is observed that the roadway deformation (roof, floor, and two sides) begins to significantly increase. Following this, when pushed to $16 \mathrm{~m}$, the deformation shows a rapid increase. The maximum cumulative movement of the roof and floor is $142 \mathrm{~mm}$, while that for the two roadway sides is $120 \mathrm{~mm}$. The values fall within an allowable movement range, thereby proving that the support can satisfy the normal production. 


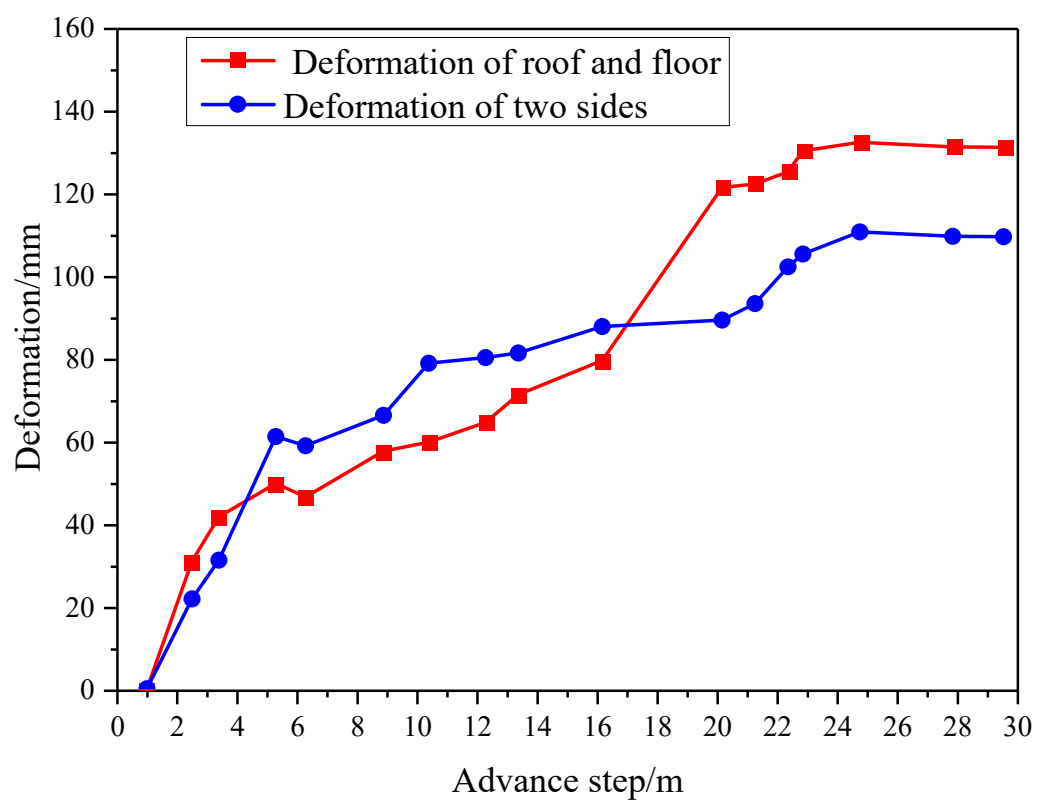

Figure 15. Deformation map on both sides of the roadway and the roof and floor.

\section{Conclusions}

(1) In coal mine gob-side entry-retaining practice, improving the production rate is a longstanding crucial issue requiring continuous and further attention from engineers and researchers. Based on this consideration, a new gob-side entry retaining approach including mixing materials, bagging and sealing, underground transportation, and staggered construction was proposed in this study.

(2) Test results showed that the uniaxial compressive strengths of the specimens comprising cement, putty powder, fly ash, sand, and accelerator prepared using a defined proportion and cured for 3,7 , and 28 days (12.91 $\mathrm{MPa}, 18.82 \mathrm{MPa}$, and $26.84 \mathrm{MPa}$, respectively) were all greater than the support wall resistance $(4 \mathrm{MPa})$.

(3) Using the 8101 working face as the background, the efficacy of the proposed method involving the use of bag filling material for wall construction was verified. Compared with the concrete grouted wall and paste filling methods, the gob-side entry retaining involving bag filling material for wall construction is a relatively simple technology characterized by rapid roadway formation.

(4) The stress and deformation law simulated via numerical methods and monitored during field tests are basically consistent. The peak of stress and deformation obtained by field tests are slightly smaller than those obtained by numerical simulation. The monitoring results show that the deformation of roadway is small, which can meet the production demand of coal mine.

Author Contributions: Conceptualization, Z.D.; methodology, Z.D. and S.C.; investigation Z.D., S.C. and Z.G.; writing-review and editing, Z.D., S.C., J.M. and D.Y. All authors have read and agreed to the published version of the manuscript.

Funding: This study was supported by the National Key R\&D Program of China (2018YFC0604704), the National Natural Science Foundation of China (51774194), the Shandong Provincial Natural Science Fund for Distinguished Young Scholars (JQ201612), the Shandong Provincial Key R\&D Plan (2017GSF17112), the Shandong Provincial Natural Science Fund (ZR2018ZC0740), and the Taishan Scholars Project.

Conflicts of Interest: The authors declare no conflict of interest. 


\section{References}

1. Yang, H.; Liu, Y.; Cao, S.; Pan, R.; Wang, H.; Li, Y.; Luo, F. A caving self-stabilization bearing structure of advancing cutting roof for gob-side entry retaining with hard roof stratum. Geomech. Eng. 2020, 21, 23-33.

2. Luan, H.; Jiang, Y.-J.; Lin, H.; Li, G. Development of a New Gob-Side Entry-Retaining Approach and Its Application. Sustainability 2018, 10, 470. [CrossRef]

3. Yang, H.; Cao, S.; Wang, S.; Fan, Y.; Wang, S.; Chen, X. Adaptation assessment of gob-side entry retaining based on geological factors. Eng. Geol. 2016, 209, 143-151. [CrossRef]

4. Mu, W.; Li, L.; Guo, Z.; Du, Z.; Wang, S. Novel Segmented Roadside Plugging-Filling Mining Method and Overlying Rock Mechanical Mechanism Analyses. Energies 2019, 12, 2073. [CrossRef]

5. Zhang, N.; Yuan, L.; Han, C.; Xue, J.; Kan, J. Stability and deformation of surrounding rock in pillarless gob-side entry retaining. Saf. Sci. 2012, 50, 593-599. [CrossRef]

6. Wang, J.; Zhang, J.; Li, Z. A new research system for caving mechanism analysis and its application to sublevel top-coal caving mining. Int. J. Rock Mech. Min. Sci. 2016, 88, 273-285. [CrossRef]

7. Cui, F.; Yang, Y.; Lai, X.; Jia, C.; Shan, P. Experimental Study on the Effect of Advancing Speed and Stoping Time on the Energy Release of Overburden in an Upward Mining Coal Working Face with a Hard Roof. Sustainability 2019, 12, 37. [CrossRef]

8. Xie, Z.; Zhang, N.; Feng, X.; Liang, D.; Wei, Q.; Weng, M. Investigation on the evolution and control of surrounding rock fracture under different supporting conditions in deep roadway during excavation period. Int. J. Rock Mech. Min. Sci. 2019, 123, 104122. [CrossRef]

9. Xie, Z.; Zhang, N.; Qian, D.; Han, C.; An, Y.; Wang, Y. Rapid Excavation and Stability Control of Deep Roadways for an Underground Coal Mine with High Production in Inner Mongolia. Sustainability 2018, 10, 1160. [CrossRef]

10. Qiu, P.; Wang, J.; Ning, J.; Liu, X.; Hu, S.; Gu, Q. Rock burst criteria of deep residual coal pillars in an underground coal mine: A case study. Geomech. Eng. 2019, 19, 499-511.

11. Tan, Y.; Ma, Q.; Zhao, Z.; Gu, Q.; Fan, D.; Song, S.; Huang, D. Cooperative bearing behaviors of roadside support and surrounding rocks along gob-side. Geomech. Eng. 2019, 18, 439-448.

12. Anagnostopoulos, T.; Kyriakopoulos, G.L.; Ntanos, S.; Gkika, E.; Asonitou, S. Intelligent Predictive Analytics for Sustainable Business Investment in Renewable Energy Sources. Sustainability 2020, 12, 2817. [CrossRef]

13. Gao, D.; Liu, Y.; Wang, T.; Wang, D. Experimental Investigation of the Impact of Coal Fines Migration on Coal Core Water Flooding. Sustainability 2018, 10, 4102. [CrossRef]

14. Dong, S.; Wang, Z.; Li, Y.; Li, F.; Li, Z.; Chen, F.; Cheng, H. Assessment of Comprehensive Effects and Optimization of a Circular Economy System of Coal Power and Cement in Kongtong District, Pingliang City, Gansu Province, China. Sustainability 2017, 9, 787. [CrossRef]

15. Zhao, J.; Yin, L.; Guo, W. Stress-Seepage Coupling of Cataclastic Rock Masses Based on Digital Image Technologies. Rock Mech. Rock Eng. 2018, 51, 2355-2372. [CrossRef]

16. Zhao, J.; Zhang, X.; Jiang, N.; Yin, L.; Guo, W. Porosity zoning characteristics of fault floor under fluid-solid coupling. Bull. Int. Assoc. Eng. Geol. 2020, 79, 2529-2541. [CrossRef]

17. Zhang, Y.; Tang, J.; Xiao, D.; Sun, L.; Zhang, W. Spontaneous caving and gob-side entry retaining of thin seam with large inclined angle. Int. J. Min. Sci. Technol. 2014, 24, 441-445. [CrossRef]

18. Zhou, B.; Xu, J.; Zhao, M.; Zeng, Q. Stability study on naturally filling body in gob-side entry retaining. Int. J. Min. Sci. Technol. 2012, 22, 423-427. [CrossRef]

19. Tan, Y.; Yu, F.; Ning, J.; Zhao, T. Design and construction of entry retaining wall along a gob side under hard roof stratum. Int. J. Rock Mech. Min. Sci. 2015, 77, 115-121. [CrossRef]

20. Wang, H.; Zhang, D.; Fan, G. Structural effect of a soft\&ndash;hard backfill wall in a gob-side roadway. Min. Sci. Technol. (China) 2011, 21, 313-318. [CrossRef]

21. Yuehua, D.; Jianxin, T.; Xiangke, Z.; Yong, F.U.; Zhangyin, D.A.I. Analysis and application in controlling surrounding rock of support reinforced roadway in gob-side entry with fully mechanized mining. Min. Sci. Technol. (China) 2010, 20, 839-845. [CrossRef] 
22. Su, H.; Bai, J.; Yan, S.; Chen, Y.; Zhang, Z. Study on gob-side entry retaining in fully-mechanized longwall with top-coal caving and its application. Int. J. Min. Sci. Technol. 2015, 25, 503-510. [CrossRef]

23. Yang, J.; He, M.; Cao, C. Design principles and key technologies of gob side entry retaining by roof pre-fracturing. Tunn. Undergr. Space Technol. 2019, 90, 309-318. [CrossRef]

24. Gao, Y.; Wang, Y.; Yang, J.; Zhang, X.; He, M. Meso- and macroeffects of roof split blasting on the stability of gateroad surroundings in an innovative nonpillar mining method. Tunn. Undergr. Space Technol. 2019, 90, 99-118. [CrossRef]

25. Wang, Q.; He, M.; Yang, J.; Gao, H.; Jiang, B.; Yu, H. Study of a no-pillar mining technique with automatically formed gob-side entry retaining for longwall mining in coal mines. Int. J. Rock Mech. Min. Sci. 2018, 110, 1-8. [CrossRef]

26. Yang, H.; Han, C.; Zhang, N.; Sun, C.; Pan, D.; Dong, M. Stability Control of a Goaf-Side Roadway under the Mining Disturbance of an Adjacent Coal Working Face in an Underground Mine. Sustainability 2019, 11, 6398. [CrossRef]

27. Zhang, X.; Chen, L.; Gao, Y.; Hu, J.; Yang, J.; He, M. Study of An Innovative Approach of Roof Presplitting for Gob-Side Entry Retaining in Longwall Coal Mining. Energies 2019, 12, 3316. [CrossRef]

28. Sun, Q.; Zhang, J.; Huang, Y.; Yin, W. Failure Mechanism and Deformation Characteristics of Gob-Side Entry Retaining in Solid Backfill Mining: A Case Study. Nat. Resour. Res. 2019, 29, 1-15. [CrossRef]

29. Xie, Z.; Zhang, N.; Meng, F.; Han, C.; An, Y.; Zhu, R. Deformation Field Evolution and Failure Mechanisms of Coal-Rock Combination Based on the Digital Speckle Correlation Method. Energies 2019, 12, 2511. [CrossRef]

30. Xie, Z.; Zhang, N.; Yuan, Y.; Xu, G.; Wei, Q. Study on Safety Control of Composite Roof in Deep Roadway Based on Energy Balance Theory. Sustainability 2019, 11, 3688. [CrossRef]

31. Chen, S.; Yin, D.; Jiang, N.; Wang, F.; Zhao, Z. Mechanical properties of oil shale-coal composite samples. Int. J. Rock Mech. Min. Sci. 2019, 123, 104120. [CrossRef]

32. Chen, Y.; Bai, J.; Yan, S.; Xu, Y.; Wang, X.; Ma, S. Control mechanism and technique of floor heave with reinforcing solid coal side and floor corner in god-side coal entry retaining. Int. J. Min. Sci. Technol. 2012, 22, 841-845. [CrossRef]

33. Liu, L.; Xin, J.; Huan, C.; Qi, C.; Zhou, W.; Song, K.-I. Pore and strength characteristics of cemented paste backfill using sulphide tailings: Effect of sulphur content. Constr. Build. Mater. 2020, 237, 117452. [CrossRef]

34. Sun, Q.; Tian, S.; Sun, Q.; Li, B.; Xia, Y.; Wei, X.; Mu, Q. Preparation and microstructure of fly ash geopolymer paste backfill material. J. Clean. Prod. 2019, 225, 376-390. [CrossRef]

35. Chen, S.; Du, Z.; Zhang, Z.; Zhang, H.; Xia, Z.; Feng, F. Effects of chloride on the early mechanical properties and microstructure of gangue-cemented paste backfill. Constr. Build. Mater. 2020, 235, 117504. [CrossRef]

36. Chen, S.; Du, Z.; Zhang, Z.; Yin, D.; Feng, F.; Ma, J. Effects of red mud additions on gangue-cemented paste backfill properties. Powder Technol. 2020, 367, 833-840. [CrossRef]

37. Zhang, C.; Jin, Z.; Feng, G.; Song, X.; Rui, G.; Yujiang, Z. Double Peaked Stress-Strain Behavior and Progressive Failure Mechanism of Encased Coal Pillars Under Uniaxial Compression. Rock Mech. Rock Eng. 2020, 1-14. [CrossRef]

38. Feng, F.; Chen, S.; Li, D.; Huang, W.; Peng, K.; Zang, C. Excavation unloading-induced fracturing of hard rock containing different shapes of central holes affected by unloading rates and in situ stresses. Energy Sci. Eng. 2019, 8, 4-27. [CrossRef]

39. Lin, G.; Teng, J.G. Advanced stress-strain model for FRP-confined concrete in square columns. Compos. Part. B Eng. 2020, 197, 108149. [CrossRef]

40. Wu, F.; Deng, Y.; Wu, J.; Li, B.; Sha, P.; Guan, S.; Zhang, K.; He, K.; Liu, H.; Qiu, S. Stress-strain relationship in elastic stage of fractured rock mass. Eng. Geol. 2020, 268, 105498. [CrossRef]

41. Fang, K.; Cui, L.; Fall, M. A coupled chemo-elastic cohesive zone model for backfill-rock interface. Comput. Geotech. 2020, 125, 103666. [CrossRef]

42. Wang, Q.; Jiang, Z.; Jiang, B.; Gao, H.; Huang, Y.; Zhang, P. Research on an automatic roadway formation method in deep mining areas by roof cutting with high-strength bolt-grouting. Int. J. Rock Mech. Min. Sci. 2020, 128, 104264. [CrossRef] 
43. Sun, J. Mechanics criterion and factors affecting overburden stability in solid dense filling mining. Int. J. Min. Sci. Technol. 2017, 27, 407-413. [CrossRef]

44. Yan, H.; He, F.; Yang, T.; Li, L.; Zhang, S.; Zhang, J. The mechanism of bedding separation in roof strata overlying a roadway within a thick coal seam: A case study from the Pingshuo Coalfield, China. Eng. Fail. Anal. 2016, 62, 75-92. [CrossRef]

45. Wu, G.; Chen, W.; Jia, S.; Tan, X.; Zheng, P.; Tian, H.; Rong, C. Deformation characteristics of a roadway in steeply inclined formations and its improved support. Int. J. Rock Mech. Min. Sci. 2020, 130, 104324. [CrossRef]

46. Zhao, X.; Li, H.; Zhang, S.; Yang, X. Stability Analyses and Cable Bolt Support Design for A Deep Large-Span Stope at the Hongtoushan Mine, China. Sustainability 2019, 11, 6134. [CrossRef]

47. Yang, H.; Han, C.; Zhang, N.; Sun, Y.; Pan, D.; Sun, C. Long High-Performance Sustainable Bolt Technology for the Deep Coal Roadway Roof: A Case Study. Sustainability 2020, 12, 1375. [CrossRef]

(C) 2020 by the authors. Licensee MDPI, Basel, Switzerland. This article is an open access article distributed under the terms and conditions of the Creative Commons Attribution (CC BY) license (http://creativecommons.org/licenses/by/4.0/). 